\section{PEDAGOGIA E PEDAGOGOS, PARA QUÊ?}

José Carlos Libâneo

São Paulo: Cortez, 2005. 200p. (8. ed.)

O livro reúne textos escritos ao longo da década de 1990 por José Carlos Libâneo com a intenção de responder à pergunta que dá título à obra. Como se trata de um autor cujo pensamento é amplamente conhecido nos meios educacionais, as respostas são familiares àqueles que têm se interessado pelos destinos da pedagogia no Brasil, constituindo-se em autêntico manifesto em favor da pedagogia e, conseqüentemente, da profissão de pedagogo.

Em um manifesto são declaradas, publicamente, as razões que justificam certos atos e opções. É isso que faz o autor ao longo dos cinco capítulos do livro, expondo as razões que justificam a existência da pedagogia como "ciência da educação", posicionando-se em favor da especificidade da atuação profissional do pedagogo e formulando uma clara proposta para a sua formação.

Para Libâneo, o que justifica a existência da pedagogia é o fato de esse campo ocuparse do estudo sistemático das práticas educativas que se realizam em sociedade como processos fundamentais da condição humana. A pedagogia, segundo o autor, serve para investigar a natureza, as finalidades e os processos necessários às práticas educativas com o objetivo de propor a realização desses processos nos vários contextos em que essas práticas ocorrem. Ela se constitui, sob esse entendimento, em um campo de conhecimento que possui objeto, problemáticas e métodos próprios de investigação, configurando-se como "ciência da educação".

Essa visão da pedagogia fundamenta-se em um conceito ampliado de educação. Para
Libâneo, as práticas educativas não se restringem à escola ou à família. Elas ocorrem em todos os contextos e âmbitos da existência individual e social humana, de modo institucionalizado ou não, sob várias modalidades. Entre essas práticas, há as que acontecem de forma difusa e dispersa, são as que ocorrem nos processos de aquisição de saberes e modos de ação de moda não intencional e não institucionalizado, configurando a educação informal. Há, também, as práticas educativas realizadas em instituições não convencionais de educação, mas com certo nível de intencionalidade e sistematização, tais como as que se verificam nas organizações profissionais, nos meios de comunicação, nas agências formativas para grupos sociais específicos, caracterizando a educação não formal. Existem, ainda, as práticas educativas com elevados graus de intencionalidade, sistematização e institucionalização, como as que se realizam nas escolas ou em outras instituições de ensino, compreendendo o que o autor denomina educação formal.

Para Libâneo, são esses processos que constituem o objeto de estudo da pedagogia, demarcando-Ihe um campo próprio de investigação. Ela estuda as práticas educativas tendo em vista explicitar finalidades, objetivos sociopolíticos e formas de intervenção pedagógica para a educação. O pedagógico da ação educativa se expressa, justamente, na intencionalidade e no direcionamento dessa ação. Esse posicionamento é necessário, defende o autor, porque as práticas educativas não se dão de forma isolada das relações sociais, políticas, culturais e econômicas da sociedade. Vivemos em uma sociedade desigual, baseada em relações sociais de antagonismo e de exploração. Por isso a pedagogia não se pode eximir de se posicionar claramente sobre qual direção a ação educativa deve tomar, sobre que tipo de homem pretende formar. Do ponto de vista do 
autor isso é o que justifica a existência da pedagogia como área do conhecimento, cuja especificidade é realizar uma reflexão global e unificadora da realidade da educação.

Nessa concepção, pedagogo é o profissional que atua em várias instâncias da prática educativa, indireta ou diretamente vinculadas à organização e aos processos de aquisição de saberes e modos de ação, com base em objetivos de formação humana definidos em uma determinada perspectiva. Dentre essas instâncias, o pedagogo pode atuar nos sistemas macro, intermediário ou micro de ensino (gestores, supervisores, administradores, planejadores de políticas educacionais, pesquisadores ou outros); nas escolas (professores, gestores, coordenadores pedagógicos, pesquisadores, formadores etc.); nas instâncias educativas não escolares (formadores, consultores, técnicos, orientadores que ocupam de atividades pedagógicas em empresas, órgãos públicos, movimentos sociais, meios de comunicação; na produção de vídeos, filmes, brinquedos, nas editoras, na formação profissional etc.).

Essa formulação distingue claramente a atividade profissional do professor, que realiza uma forma específica de trabalho pedagógico (ensino) e a atividade profissional do pedagogo, que se desenvolve em um amplo leque de práticas educativas (informais, não formais e formais). Por isso Libâneo entende que a formação do professor e a do pedagogo não podem ser realizadas em um único curso, tal como defendem os movimentos de reformulação dos cursos de formação de educadores, atualmente representados pela Associação Nacional pela Formação dos Profissionais da Educação - Anfope.

A proposta do autor é a de que haja dois cursos, um de pedagogia para formar o pedagogo stricto sensu e um de licenciatura para formar professores para os níveis fundamen- tal e médio de ensino. Em síntese, ela consiste dos seguintes pontos: a. as faculdades de educação ofereceriam dois cursos distintos, um de pedagogia e um de licenciatura para a docência no ensino fundamental e médio; $b$. o pedagogo receberia formação especializada através de habilitações, entre elas a pedagogia escolar; c. o licenciado obteria habilitações para a docência no curso de magistério, nas disciplinas de $5^{a}$ a $8^{a}$ série e ensino médio ou nas séries iniciais do ensino fundamental; e $d$. a estrutura curricular teria uma base comum, englobando conhecimentos referentes aos fundamentos da educação, da escola e do ensino e de uma parte específica de conhecimentos profissionais, definidos conforme o contexto de atuação profissional (pedagogo, docente ou outra habilitação).

Trata-se de uma proposta coerente com uma visão de educação como prática social que, por não restringir o educativo ao âmbito do escolar, abre o campo de exercício profissional do pedagogo. Desde quando foi apresentada pela primeira vez, no $6^{\circ}$ Encontro Nacional da Anfope, realizado em 1992, em Belo Horizonte, a proposta tem sido objeto de polêmicas e discordâncias com esse movimento, que defende a docência como base da identidade profissional do pedagogo, subsumindo o trabalho pedagógico ao trabalho docente. No entanto, tem sido coerentemente defendida pelo autor em congressos, simpósios, encontros e debates da área, nos quais a posição da Anfope foi sempre hegemônica. Assim como faz nestes eventos, com esta publicação o autor apresenta seus argumentos em favor da especificidade da pedagogia, dos estudos pedagógicos e do exercício profissional do pedagogo, conclamando os pedagogos a influírem nos rumos de sua profissão, tal como o faz em um dos capítulos, intitulado "Que destinos os educadores darão à pedago- 
Resenhas

gia?" Com a palavra os pedagogos. A leitura do livro pode ser uma boa fonte de argumentos para a construção desses destinos.

Verbena Moreira Soares de Sousa Lisita Faculdade de Educação da Universidade Federal de Goiás lisita@uol.com.br 